\title{
KANDUNGAN SERAT KASAR HIJAUAN RAMI (Boehmeria nivea L. Gaud) PADA BERBAGAI UMUR PEMOTONGAN
}

\author{
(Crude Fiber Content Of Ramie As Forage (Boehmeria Nivea L. Gaud) At Different \\ Cutting Ages)
}

\author{
I. Susilawati, S. Suryanah, Budi Ayuningsih Lizah Khairani dan Ana Rochana \\ Departemen Nutrisi Ternak dan Teknologi Pakan, Fakultas Peternakan, \\ Universitas Padjadjaran, Jl. Bandung - Sumedang, km 21 Sumedang 45363 \\ Telp/Fax : 022-7798241/022-7798212, E-mail : iin.susilawati@unpad.ac.id
}

Article Submitted : 17-12-2018

Article Accepted : 14-01-2019

\begin{abstract}
This study was aimed to determine the effect of different cutting age on the crude fiber content of ramie (Boehmeria nivea L. Gaud) as forage, and to know the optimum cutting age of ramie for ruminant feed. The research was carried out in Margamulya Village, Cikandang District, Garut Regency, from August to October 2018. Crude fiber analysis was carried out at the Ruminant Animal Nutrition Laboratory and Animal Food Chemistry, Faculty of Animal Husbandry, Padjadjaran University. The study used a completely randomized design with four (4) treatments and five (5) replications, i.e. P1 $=15$ days of cutting age, $\mathrm{P} 2=30$ days of cutting age, $\mathrm{P} 3=45$ days of cutting age, $\mathrm{P} 4=60$ days of cutting age. To find out the differences in effects between treatments, Duncan's multiple range test was carried out. The results showed that the cutting age affected the crude fiber content of ramie. The older cutting age had the increased crude fiber content. The optimum cutting frequency of ramie for forage was 30 days with ADF content $38 \%$, NDF 53.2\%, hemicellulose $34.1 \%$, cellulose $14.8 \%$ and lignin $4.0 \%$
\end{abstract}

Keywords: cutting age, Ramie, Crude Fiber, forage.

\section{PENDAHULUAN}

Tanaman rami awalnya ditanam dengan tujuan untuk diambil seratnya yang berasal dari batangnya sebagai bahan baku pabrik tekstil, dan bagian yang dimanfaatkan sebagai hijauan pakan adalah limbahnya, yaitu daun rami dan batang yang masih muda. Hijauan pakan yang berasal dari rami ini ternyata disukai ternak ruminansia dan memiliki kandungan nutrient yang cukup tinggi. Menurut FAO (2005), tanaman rami per ha dapat menghasilkan hijauan segar sampai 300 ton segar per tahun setara dengan 42 ton bahan kering. Menurut Suryanah dkk. (2017), pada umur potong 30 hari, hijauan rami mempunyai kandungan protein kasar
$29,20 \%$ dan serat kasar 29,44\%, sedangkan pada umur potong 45 hari mempunyai kandungan protein kasar dan $24,58 \%$, serat kasar 39,57\%.

Tanuwiria dkk (2010) menyatakan bahwa daun rami yang dibuat tepung dapat mensubstitusi konsentrat sampai $35 \%$ pada ternak domba atau $15 \%$ dalam ransum secara keseluruhan. Ayuningsih (2014) juga meneliti bahwa hijauan rami yang dibuat silase dapat menggantikan $100 \%$ hijauan yang tadinya berasal dari rumput pada ternak domba Garut, dan pemberian ransum dengan perbandingan $60 \%$ silase rami dan $40 \%$ konsentrat menghasilkan pertambahan berat badan harian tertinggi yaitu 111 gram. 
Melihat potensi yang cukup tinggi pada tanaman rami, maka tanaman rami ini dapat dibudidayakan secara khusus untuk tujuan penghasil hijauan pakan.

Tanaman rami dapat ditanam secara monokultur, maupun mixcropping dengan tanaman lain. Tanaman rami juga merupakan tanaman yang relatif tahan naungan sehingga dapat ditanam di antara tegakan pohon kayukayuan atau bisa ditanam di antara pohon pisang. Selain itu tanaman rami relatif tahan kering sehingga masih dapat menghasilkan hijauan pakan yang cukup walaupun di musim kemarau.

Produksi dan kandungan nutrient hijauan pakan dipengaruhi oleh jenis tanaman, umur pemotongan, iklim dan kesuburan tanah (Kartasapoetra, 1991). Umur pemotongan merupakan salah satu faktor penting karena semakin tua umur pemotongan produksi hijauan akan semakin tinggi namun kualitasnya akan menurun. Kandungan protein akan menurun dan sebaliknya kandungan serat kasar akan meningkat, karena itu untuk mendapatkan hasil yang optimal perlu diketahui interval pemotongan yang tepat supaya diperoleh produksi dan kualitas hijauan yang tinggi. Interval pemotongan yaitu selang waktu antara satu pemotongan dengan pemotongan berikutnya. Menurut Van Soest (1994), umur pemotongan yang tepat pada hijauan adalah ketika fase late vegetative sampai early bloom yang ditandai dengan munculnya bunga sekitar $10 \%$. Tanaman rami khususnya klon Pujon mulai berbunga antara 20-30 hari setelah dipangkas (Balittas, 2014). Hasan (2012) menyatakan bahwa jika hijauan dipanen terlalu muda maka kandungan proteinnya tinggi, serat kasar rendah tetapi produksi hijauan rendah. Selain itu kemampuan untuk tumbuh kembali rendah karena kandungan karbohidrat pada bagian batang yang disisakan rendah. Jika hijauan dipotong terlalu tua akan mempunyai kandungan protein yang rendah, serat kasar tinggi walaupun produksinya lebih tinggi tetapi palatabilitasnya rendah. Keuntungan tanaman yang dipotong pada saat late vegetative atau early bloom yaitu nilai gizi cukup, serat kasar belum terlalu tinggi, produksi hijauan cukup tinggi, palatabilitas masih baik, dan kemampuan untuk tumbuh kemabali tinggi karena kandungan karbohidrat pada bagian batang yang tersisa tinggi.

\section{METODE PENELITIAN}

$\begin{array}{ccc}\text { Penelitian } & \text { dilaksanakan di Desa } \\ \text { Margamulya, } & \text { Kecamatan } & \text { Cikandang }\end{array}$
Kabupaten Garut, dari bulan Agustus sampai Oktober 2014. Tanaman rami sebagai bahan penelitian adalah tanaman rami klon pujon 10 yang telah ditanam selama 4 tahun di bawah tegakan pohon kayu-kayuan. Lokasi berada pada ketinggian $\pm 1.310 \mathrm{~m}$ dari permukaan laut. Suhu antara $19^{\circ}-26^{\circ}$, curah hujan rata-rata per tahun $2500 \mathrm{~mm}$. Petakpetak penelitian dibuat dengan ukuran 2 x 2 m. Pemotongan awal (trimming) dilakukan serempak pada semua bahan penelitian dengan tinggi pemotongan $\pm 6 \mathrm{~cm}$ dari permukaan tanah. Pemanenan pada setiap petak dilakukan sesuai dengan perlakuan yaitu $\mathrm{P}_{1}=$ umur pemotongan 15 hari, $\mathrm{P}_{2}=$ umur pemotongan 30 hari, $\mathrm{P}_{3}=$ umur pemotongan 45 hari, $\mathrm{P}_{4}=$ umur pemotongan 60 hari. Sampel hijauan segar ditimbang sebanyak 500 gram kemudian dipotongpotong sekitar $5 \mathrm{~cm}$. Setelah itu sampel dikeringkan dengan menggunakan oven suhu $70^{\circ}$ selama $2 \times 24$ jam untuk mendapatkan berat kering. Selanjutnya dianalisis kandungan nutriennya termasuk kandungan fraksi serat dengan menggunakan metode Van Soest (1970).

Rancangan percobaan yang digunakan yaituRancangan Acak Lengkap (RAL), dengan 4 perlakuan dan 5 kali ulangan. Uji lanjut untuk melihat perbedaan antar perlakuan menggunakan Uji Jarak Berganda Duncan. Peubah yang diukur yaitu fraksi serat kasar terdiri atas netral detergent fiber (NDF), acid detergent Fiber (ADF), selulosa dan hemiselulosa. 


\section{HASIL DAN PEMBAHASAN}

Data kandungan fraksi serat hijauan rami yang dipotong pada berbagai umur, dicantumkan pada Tabel 1 .
Berdasarkan tabel 1 dapat dilihat bahwa kandungan semua fraksi serat kasar ( ADF, NDF, selulosa dan hemiselulosa) meningkat sejalan dengan meningkatnya umur pemotongan.

Tabel 1. Kandungan Fraksi Serat Kasar Hijauan Rami pada Berbagai Umur Pemotongan

\begin{tabular}{cccccc}
\hline \multirow{2}{*}{ Perlakuan } & ADF & NDF & Selulosa & Hemiselulosa & Lignin* \\
\cline { 2 - 6 } & $\%$ & $\%$ & $\%$ & $\%$ & $\%$ \\
\hline Umur pemotongan 15 hari & $34,29^{\mathrm{a}}$ & $42,90^{\mathrm{a}}$ & $31,59^{\mathrm{a}}$ & $8,60^{\mathrm{a}}$ & $2,70^{\mathrm{a}}$ \\
Umur pemotongan 30 hari & $38,32^{\mathrm{b}}$ & $53,15^{\mathrm{b}}$ & $34,14^{\mathrm{b}}$ & $14,82^{\mathrm{b}}$ & $4,20^{\mathrm{b}}$ \\
Umur pemotongan 45 hari & $42,62^{\mathrm{c}}$ & $60,52^{\mathrm{c}}$ & $35,35^{\mathrm{c}}$ & $18,77^{\mathrm{c}}$ & $7,27^{\mathrm{c}}$ \\
Umur pemotongan 60 hari & $50,31^{\mathrm{d}}$ & $69,09^{\mathrm{d}}$ & $40,43^{\mathrm{d}}$ & $19,90^{\mathrm{d}}$ & $9,88^{\mathrm{d}}$ \\
\hline
\end{tabular}

$*=$ Suryanah, dkk. 2017

Hal ini sejalan dengan penelitian Tessema dkk (2010) yang menyatakan bahwa bertambahnya lama frekuensi pemotongan akan menambah Kandungan ADF, NDF dan selulosa pada rumput Gajah. Kandungan NDF pada umur pemotongan 15 hari dan 30 hari adalah $42,90 \%$ dan $53,15 \%$, di bawah kandungan NDF yang direkomendasikan oleh Meissner et al. (1991) yaitu harus di bawah 60\%, jika lebih dari $60 \%$ akan memberikan pengaruh negatif bagi pencernaan ruminansia. Pemotongan umur 45 dan 60 hari pada tanaman rami menghasilkan kandungan NDF hijauan lebih dari $60 \%$ yaitu $60,52 \%$ dan $69,09 \%$.

Selulosa adalah zat penyusun tanaman yang terdapat cukup banyak sebagai material stuktur dinding sel semua tanaman. Kandungan selulosa pada dinding sel tanaman tingkat tinggi sekitar $35-50 \%$ dari berat kering tanaman. Menurut Tillman et al. (1989), Hemiselulosa adalah polisakarida pada dinding sel tanaman yang larut dalam alkali dan menyatu dengan selulosa. Selulosa dan hemiselulosa dapat dihidrolisa oleh jasad renik dalam saluran pencernaan ruminansia dengan enzim selulase dan hemiselulase, hasil fermentasinya adalah VFA (Volatile Fatty Acid). Jumlah hemiselulosa biasanya antara $15-30 \%$ dari berat kering hijauan. Hemiselulosa mengikat lembaran serat selulosa membentuk mikofibril yang meningkatkan stabilitas dinding sel. Hemiselulosa juga berikatan silang dengan lignin membentuk jaringan yang komplek dan memberi struktur yang kuat.

Lignin adalah gabungan beberapa senyawa yang hubungannya erat satu sama lain, mengandung karbon, hydrogen dan oksigen, namun proporsi karbonnya lebih tinggi dibanding senyawa karbohidrat. Lignin sangat tahan terhadap degradasi kimia termasuk degradasi enzimatik, karena itu keberadaannya dapat menghambat proses pencernaan. Kandungan lignin pada tanaman akan bertambah seiring bertambahnya umur tanaman dan mencapai level tertinggi pada saat tanaman sudah dewasa (Tillman et al., 1989). Menurut Zulbadri dkk (1999), batas optimal lignin yang masih dapat ditoleransi oleh ternak ruminansia adalah 7\%, jika lebih dari $7 \%$ akan berpengaruh terhadap kecernaan zat-zat pakan lainnya karena itu, hijauan pakan yang menganbdung lignin yang tinggi, mempunyai tingkat kecernaan yang rendah.

\section{KESIMPULAN}

Berdasarkan hasil penelitian yang telah dilakukan maka dapat disimpulkan bahwa semakin lama umur pemotongan maka kandungan fraksi serat semakin meningkat. Interval pemotongan rami yang tepat untuk hijauan pakan adalah setiap 30 
hari, karena kandungan fraksi seratnya yang tidak terlalu tinggi, yaitu ADF 38\%, NDF $\quad 53,15 \%$, selulosa $34,14 \%$, hemiselulosa $14,82 \%$ dan kandungan ligninnya $4,20 \%$.

\section{DAFTAR PUSTAKA}

Ayuningsih, B. 2014. Evaluasi Ransum mengandung Silase Daun Rami dan Implementasinya pada Domba Garut. Disertasi. Pasca UNPAD, Bandung.

Balittas (Balai Penelitian Tanaman Pemanis dan Serat). 2014. Varietas Unggul Rami (online) available at http://perkebunan litbang.deptan.go.id (verified March, 2014).

Hasan, S. 2012. Hijauan Pakan Tropik. IPB Press, Bogor.

Kartasapoetra, A.G. 1991. Pengantar Anatomi Tumbuh-Tumbuhan. Rineka Cipta, Jakarta.

Meissner, H.H., H.H. Koster, S.H. Nieuwoudt and R.J. Coetze. 1991. Effect of Energy Supplementation on intake and Digestion of Early and Mid-season Ryegrass and Panicum/SmutFinger Hay, and in Sacco disappearance of various forage species. South African Journal of animal Science. 21: 33 -42.
Suryanah, S., Ana Rochana, Iin Susilawati dan Nyimas Popi Indriani. 2017. Ramie (Boehmeria nivea) Plant Nutrient Quality as Feed Forage at Various Cutting Ages. Anim.Product.19(2):111-117.

Tanuwiria, U.H., A. Rochana, S.P. Agustin, R. Rizaldi dan L.S. Pratama. 2010. Daun Rami (Boehmeria nivea) sebagai Pengganti Konsentrat Ransum Domba. Prosiding Seminar Nasional Fakultas Peternakan Unpad ke-2: 494-498.

Tessema, Z.K., J. Mihret and M. Solomon. 2010. Effect of Defoliation Frequency and Cutting Height on Growth, Dry Matter Yield and Nutritive Value of Napier Grass. Grass and Forage Sci. 65: 421-430.

Tillman, A.D., H. Hartadi, S. Reksohadiprodjo, Prawirokusumo dan S. Lebdosoekojo. 1989. Ilmu Makanan Ternak Dasar. Gadjah Mada University Press, Yogyakarta.

Van Soest, P.J. 1994. Nutritional Ecology of the Ruminant ( $2^{\text {nd }}$ ed). Ithaca, New York.

Zulbadri, M.T., Sugiarti, N. Hidayati dan A.A. Karto. 1999. Peluang Pemanfaatan Limbah Tanaman Tebu untuk Penggemukan Sapi Potong di Lahan Kering. Wartazoa 8(2):33-37. 